\title{
COMPARATIVE CYCLIC BEHAVIOR OF AN AGRICULTURAL ECONOMY: NEBRASKA IN THE 70s AND 80s
}

\author{
Roger F. Riefler*
}

During the period extending from 1970 to 1984 the U.S. economy went through several recessions. Two of these recessions, the November 1973 to March 1975 and July 1981 to November 1982 downturns, could be considered "major" recessions. In the 1973-1975 episode, unemployment rates increased from a seasonally adjusted 4.7 percent to 8.7 percent; this represented a roughly 85 percent increase in this sensitive indicator of economic activity. In the 1981-1982 recession, unemployment rates rose from 7.0 percent, a level still reflecting the lack of a robust recovery from the 1979-1980 recession, to 10.6 percent seasonally adjusted. While one might quibble over just what distinguishes major from minor recessions, it is clear that in the post-World War II context both these recessions belong to the major classification.

The similarity of these two recessions extends beyond the severity of their amplitude as measured by unemployment rates. Both recessions, as benchmarked by the National Bureau of Economic Research (NBER), extend a total of 17 months from peak to trough. In both recessions unemployment increased as not only new entrants into the labor market were unable to find jobs, but also as the number of existing jobs declined. Nationally, total nonagricultural employment declined by slightly more than 2 percent from peak to trough in both recessions. Decline was especially severe in manufacturing where job loss was roughly 10 percent.

Given the industrial composition of the national recessions and the economic base of the state of Nebraska, it is not surprising that the state was spared the full brunt of the downturns. In the 1973-1975 recession Nebraska's unemployment rate went up from 2.7 percent in November 1973 to 4.3 percent in March 1975; this represents a 59 percent increase. ${ }^{1} \mathrm{~A}$ similar increase from 3.9 percent to 6.2 percent was recorded between July 1981 and

\footnotetext{
*Professor of Economics, University of Nebraska-Lincoln.
}

November 1982. Employment declines in the state ranged from 1.3 percent in the earlier recession to 1.5 percent in the more recent episode; in both cases the decline was 60 to 65 percent of that recorded at the national level.

For the regional scientist, the similarity between the two national recessions and that of Nebraska's response to these phenomena suggests a fertile ground for testing the stability of industrial mix and regional competitive effects as isolated by shift/share analysis. Table 1 contains a summary of the results of such an exercise where:

(1) Net Shift (N) $=e^{i}{ }_{t}\left(E_{t} / E_{t-1}-1\right)$

(2) Industrial Mix (I) $=e_{t}^{i}\left(E_{t}^{i} / E_{t-1}^{i}\right.$ $\left.-\mathrm{E}_{\mathrm{t}} / \mathrm{E}_{\mathrm{t}-1}\right)$

(3) Regional Effect (R) $=e^{i}{ }_{t}\left(e^{i}{ }_{t} / e^{i_{t}}-1\right.$ $\left.-\mathrm{E}_{\mathrm{t}}^{\mathrm{i}} / \mathrm{E}_{\mathrm{t}-1}^{\mathrm{i}}\right)$

$E_{t}\left(e_{t}\right)=$ total national (state) employment at the cycle trough, $E_{t}^{i}\left(e_{t}^{i}\right)=$ national (state) employment in industry $i$ at the cycle trough, and the $t-1$ designation indicates analogous peak employment. Since, as is well known, the results of shift/share analysis are sensitive to the degree of industrial disaggregation utilized, Appendix A of this paper contains the sectoring plan used in this and the following analysis. As is usually the case, the level of (dis)aggregation represents a compromise between what statistics are available, in this case from the U.S. Department of Labor's Employment and Earnings; the Nebraska Department of Labor's baseline adjusted monthly nonagricultural employment series; the structure of the regional economy; and what one would like to work with to insure comparability with other studies.

Table 1 illustrates that the 1981-1982 employment loss in Nebraska exceeded that in $1973-1975$ by roughly 2,000 jobs. The severity of the 1981-1982 national recession, combined with a larger job base in the state, alone accounted for an increment of 3,352 in the job 
Table 1

NEBRASKA SHIFT/SHARE ANALYSIS: TOTAL EFFECTS

1973-1975 RECESSION 1981-1982 RECESSION

\begin{tabular}{lll}
\hline \hline & $1973-1975$ & $1981-1982$ \\
\hline NET SHIFT & $-11,126$ & $-14,478$ \\
INDUSTRY MIX & $+7,374$ & $+5,723$ \\
REGIONAL EFFECT & $-3,347$ & - \\
\hline
\end{tabular}

loss during the later recession. Added to this was a job loss of an additional 1,651 positions due to the interaction of a less favorable industrial mix and the larger state employment base. Offsetting these negative factors was a gain of 3,041 jobs (versus the 1973-1975) recession), attributable to a larger job base and a relative improvement in Nebraska's competitive position-relative in the sense that the state became a more favorable location for employment retention.

While the results of the shift/share analysis are useful in identifying the impact of a specific recession on a state, they are, as noted by Arthur C. Mead and Glenworth A. Ramsay, “... at a level of detail that tends to obscure ... the differential response of a region to two recessions" (Mead and Ramsay, 1982, p. 39). As the previous paragraph indicates, application of the traditional shift/share technique to two separate recessions results in the compounding of two effects. What might be called the pure effects of changes in the net shift, industrial mix and regional competitive factors and the impact of the changing state employment base between the onset of the 1973 and 1981 recessions both affect the numbers presented in Table 1. Since our concern in this paper is to analyze the differential response of the Nebraska economy to the 1973-1975 and 1981-1982 recessions, we adopt the model suggested by Mead and Ramsay (1982) to isolate these effects, namely:

(4) $\mathrm{dChE}=\left[\left(\mathrm{E}_{1}-\mathrm{E}_{0}\right)\left(\mathrm{N}_{0}+\mathrm{I}_{0}+\mathrm{R}_{0}\right)\right]+\left[\mathrm{E}_{0}\right.$ $\left.\left[\left(\mathrm{N}_{1}-\mathrm{N}_{0}\right)+\left(\mathrm{I}_{1}-\mathrm{I}_{0}\right)+\left(\mathrm{R}_{1}-\mathrm{R}_{0}\right)\right]\right]$

where: $\mathrm{dChE}=$ the differential change in Nebraska employment 1973-1975 versus 1981-1982; $E_{0}\left(E_{1}\right)=$ a vector, over $i$ industries, indicating peak 1973 (1981) employment; $\mathrm{N}_{0}\left(\mathrm{~N}_{1}\right)=$ a vector, over $\mathrm{i}$ industries, of the net shift effect in the 1973-1975
(1981-1982) recessions; and $I_{0}\left(I_{1}\right)$ and $R_{0}\left(R_{1}\right)$ are defined analogously for the 1973-1975 (1981-1982) industrial mix and regional effects respectively.

Note that this formulation will only approximate the differential change in Nebraska employment in the 1973-1975 recession versus the 1981-1982 downturn. Using the 19731975 recession as a base, as done by equation (4), generates results similar to the use of a Laspeyres price index; an overestimate of the differential change is likely to result. What is of interest, however, is not the absolute value but the relative size and algebraic signs of the component elements.

As indicated in the Mead/Ramsay (1982) study, the first term in the brackets on the right hand side for equation (4) might be termed the "pure employment effect." Since the net shift (N), industrial mix (I), and regional effects (R) are kept constant at their 1973-1975 level, this term captures the difference in the recessions' impact on Nebraska that is due to changes in the industrial employment base between the November $1973\left(\mathrm{E}_{0}\right)$ and July 1981 $\left(E_{1}\right)$ cyclical peaks. A positive value for the pure employment effect would indicate that the change in the industrial base that had occurred between the onset of the two recessions, given the response vectors of the 1973-1975 recession $\left(\mathrm{N}_{0}, \mathrm{I}_{0}, \mathrm{R}_{0}\right)$, would tend to lessen the employment impact of the 1981-1982 recession.

Looking at the component terms of the pure employment effect, the $\mathrm{N}_{0}$ of the first term $\left(\mathrm{E}_{1}\right.$ $\left.-E_{0}\right) N_{0}$ will be negative since employment declined nationally in the $1973-1975$ recession while Nebraska employment increased between the November 1973 and July 1982 cyclical peaks; this negative sign indicates that the expected change in employment in the 19811982 recession should be larger than that in the earlier recession. If the industrial structure of Nebraska between 1973 and 1982 grew most rapidly in those areas that performed better in the 1973-1975 recession, we would expect the second term, $\left(E_{1}-E_{0}\right) I_{0}$, to be positive. Finally, if the Nebraska industrial base grew most rapidly in those sectors which performed comparatively well regionally in the 19731975 recession, the final term, $\left(E_{1}-E_{0}\right) R_{0}$, should also be positive, indicating a smaller employment change in the 1981-1982 recession than in the base period recession. 
The second bracketed term is referred to by Mead and Ramsay (1982) as the "pure recession effect." It ". . . measures the difference in the recessions' regional impact that can be attributed solely to changes in the [two] recessions' characteristics." A negative value for this bracketed term would indicate that changes in the properties of the 1981-1982 versus 1973-1975 recession served to exacerbate the effects of the later recession on Nebraska. Looking at the individual elements of the pure recession effect, the first term, $E_{0}\left(N_{1}-N_{0}\right)$, measures the most publicized aspect of recessions, the difference in national severity of the 1981-1982 versus 1973-1975 recession. Given the similar amplitude in employment terms mentioned above, we might anticipate that the absolute value of this term will be small, but negative. The sign would indicate the greater amplitude of the employment decline in the 1981-1982 recession (2.4 percent versus 2.0 percent).

The second $\left[\mathrm{E}_{0}\left(\mathrm{I}_{1}-\mathrm{I}_{0}\right)\right]$ and third $\left[\mathrm{E}_{0}\left(\mathrm{R}_{1}-\right.\right.$ $\left.R_{0}\right)$ ] elements of the pure recession effect measure the change in the industrial and regional response vectors, respectively, between the 1981-1982 and 1973-1975 recessions. A positive value for the industrial response effect would indicate a relative gain, or more specifically a smaller employment loss, due to the industrial pattern of the 1981-1982 recession. Similarly a positive value for $E_{0}\left(R_{1}\right.$ $-R_{0}$ ) would indicate an improved competitive performance by Nebraska firms in the 1981-1982 recession compared to that between November 1973 and March 1975. The sum of the industrial and regional response vectors would be indicative of just how closely the Nebraska economy "tracked" the national recession. If such a sum were equal to zero, leaving $\mathrm{E}_{0}\left(\mathrm{~N}_{1}-\mathrm{N}_{0}\right)$ as determining the pure recession effect, the Nebraska economy's performance would exhibit a high degree of congruence with the national cyclical pattern.

\section{Empirical Results}

Table 2 summarizes the results of applying the Mead/Ramsay model to the relative performance of the Nebraska economy in the 19731975 and 1981-1982 recessions. In the 19811982 recession the state lost 9,061 jobs in nonagricultural sectors of the economy, as opposed to a loss of 7,100 during the 19731975 recession, for a difference of $+1,961$. Ap-

Table 2

DECOMPOSITION OF DIFFERENTIAL EFFECT by Number and Percent

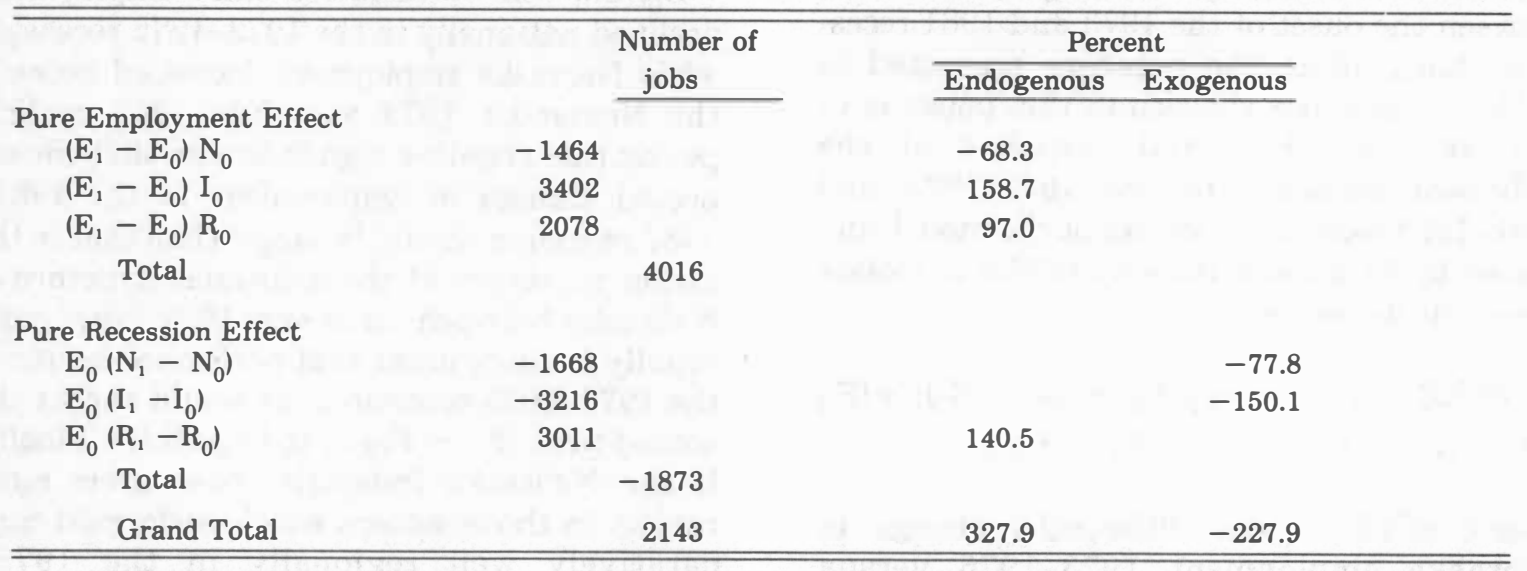


plication of equation (4) to these recessions indicates a differential of $+2,143$. Given the Laspeyres nature of the equation, this 9.3 percent overestimate of the differential was expected. While the magnitude of the overestimate is somewhat disturbing, as explained above, the sign and relative magnitude of the components of equation (4) are of prime interest. $^{3}$

Focusing on the first numerical column of Table 2 we see that pure employment effect was positive. This indicates that the change in th state's economic base from 1973 to 1981 served to dampen the regional nonagricultural impact of the later (1981-1982) recession, given the industry and regional response vectors of the 1973-1975 recession. Note the large absolute size of the pure employment effect versus the pure recession effect. Clearly employment in Nebraska shifted into industries that performed better in the 19731975 recession and this has had a significant dampening effect on employment loss in the 1981-1982 recession.

Between the cyclical peaks of 1973 and 1981, Nebraska's nonagricultural employment increased by 72,600 jobs or 13.2 percent; clearly $\mathrm{E}_{1}-\mathrm{E}_{0}$ was positive. As a result, if the 1981-1982 recession at the national level replicated that of 1973-1975 (e.g., if $\mathrm{N}_{1}=\mathrm{N}_{0}$ ), the expected job loss in the later recession would have been 1,464 jobs greater. More than offsetting this change, however, was a significant restructuring of the state's industrial base - a restructuring that proved beneficial to the state in terms of reducing the impact of the 1981-1982 recession. There was a gross redistribution of 90,000 jobs in the state. Job gains totaling 81,300 were relatively concentrated in Services (excluding personal services, 32.3 percent of the employment gain); Retail and Wholesale Trade (22.0 percent); and Finance, Insurance and Real Estate (11.3 percent)-all sectors with relative cyclical insensitivity. On the other side of the ledger the job loss of 8,700 between the 1973 and 1981 peak was relatively concentrated in Food Products (excluding meat products) and Construction, both relatively cyclically sensitive industries. ${ }^{4}$ Together these sectors accounted for 82.8 percent of job losses. As indicated in Table 2, this industrial redistribution "saved" 3,402 jobs in the 1981-1982 recession.
In a similar vein, the final component of the pure employment effect, $\left(E_{1}-E_{0}\right) R_{0}$, illustrates a significant benefit, in terms of reduced job loss in the 1981-1982 recession, garnered by the movement of employment into industries where Nebraska firms outperformed their national counterparts in the 1973-1975 recession. The Meat Products industry, which recorded an employment increase of 5,000 jobs between November 1973 and July 1981, accounted for 72 percent of the total job savings of 2,078 recorded in Table 2. Combining the industrial and regional effect of changes in the employment structure, the expected loss in employment in the 1981-1982 recession was 5,480 jobs less than the actual loss of 7,100 recorded in the 1973-1975 recession.

Recapitulating briefly, the second major element of Table 2, the pure recession effect, measures the difference in employment impact of the two recessions in Nebraska due solely to changes in the attributes of the 1981-1982 versus 1973-1975 recession. The first term, measured by $E_{0}\left(N_{1}-N_{0}\right)$ in equation (4), details the effect of the difference in overall national severity of the two recessions. Since the 1981-1982 recession was 20 percent sharper in terms of employment loss than the earlier downturn, we would expect Nebraska, ceteris paribus, to record a job loss of 1,668 more positions than in the earlier downturn. Note that in comparison to the Mead/Ramsay study (1982), which contrasted, for Massachusetts, the effect of the mild 1979-1980 recession with that of 1973-1975, the present study finds a relatively small "comparative severity" impact.

Turning to the industrial $\left(\mathrm{E}_{0}\left(\mathrm{I}_{1}-\mathrm{I}_{0}\right)\right)$ and regional $\left(E_{0}\left(R_{1}-R_{0}\right)\right)$ response vectors, we see that the 1981-1982 downturn exhibited a different pattern from that of 1973-1975. In terms of the industrial response vector, the net impact was that the changing industrial pattern of the later recession would have resulted in the net loss of 3,216 jobs. Significant in explaining this loss were the comparative behavior of employment in the Local Government; Railroad Transportation; Hotel and Lodging; Federal Government; Other Service; and Machinery sectors. Taken together, the performance of these six sectors in 1981-1982 would have resulted in an employment loss of 9,809 more jobs than in 1973-1975. To illustrate the nature of this effect, note that 
railroad employment declined 21 percent nationally from July 1981 to November 1982, versus a 6.6 percent decline in the earlier recession. The impact of this differential on Nebraska would have been the loss of 1,710 more jobs in the later recession (see Appendix B).

Partially offsetting the industry response vector was the regional response effect which, other things being equal, would have reduced the amplitude of the 1981-1982 recession in Nebraska by 3,011 jobs. The industries most responsible for this job savings were Local Government (7.5 percent growth in Nebraska during the recession versus 4.5 percent growth nationally); Construction (11 percent decline in the state versus 12 percent nationally); Hotels; Business Services; and Federal Government. Although the net impact of the combined industrial and regional response vectors is small (e.g., -205), the effect would have been to increase the magnitude of the job loss in the later recession.

\section{Policy Implications}

Following the Mead/Ramsay methodology (1982), we have divided the pure employment and pure recession impacts into exogenous and endogenous components in the final two columns of Table 2. Those parts of the differentiated effects which have the potential to be influenced by state-level policy makers are included in the endogenous column. Since state policy makers can hope to use various financial and tax incentives to influence the regional competitiveness $\left(R_{1}-R_{0}\right)$ of Nebraska, the $E_{0}$ $\left(R_{1}-R_{0}\right)$ term is potentially endogenous. Similarly, since tax/financial incentives can be used to try to alter the economic or industrial employment base $\left(E_{1}-E_{0}\right)$, each term in the pure employment effect is also endogenous.

The severity of national recessions, as measured by $\left(\mathrm{N}_{1}-\mathrm{N}_{0}\right)$, is clearly beyond the purview of individual state policy makers and therefore term $E_{0}\left(N_{1}-N_{0}\right)$ is clearly exogenous. With respect to changes in industrial performance $\left(I_{1}-I_{0}\right)$, Mead and Ramsay, since they focus only on manufacturing performance in Massachusetts, also consider this element exogenous. While we follow this precedent it should be recognized that since our study includes tertiary or nonmanufacturing sectors, this assignment might not be completely appropriate if a given state represents a signifi- cant fraction of the total national output in an industry (e.g., recreation in Florida) with a locally consumed product or service. This is not likely to be the case for a state such as Nebraska.

Unlike the Mead/Ramsay study (1982), which found the largest effects exogenous and therefore beyond the scope of state policy makers, our results indicate that there is significant potential for state policy initiatives aimed at influencing the sensitivity of the Nebraska economy to cyclical fluctuations. To a significant extent this contrast in results was foreordained by the comparative recessions used. The Mead/Ramsay study, as mentioned above, juxtapositions a relatively severe recession (1973-1975) with a relatively mild downturn (1979-1980), thus emphasizing the $\mathrm{N}_{1}$ $-\mathrm{N}_{0}$ term while we compare recessions of comparable magnitude, minimizing the influence of this term. Even considering this, however, the absolute magnitude of the percents contained in the endogenous column of Table 2 suggest considerable latitude for state-level policy effects.

While our results suggest considerable potential for state development policy in the area of reducing the cyclical vulnerability of the state's economy to national downturns, they do not indicate that realization of such an efficacious policy will be easy. The table in Appendix $\mathrm{B}$ shows the pattern, by individual sector, of the $E_{0}\left(I_{1}-I_{0}\right)$ and $E_{0}\left(R_{1}-R_{0}\right)$ terms. The lack of zero entries in this table, a result alluded to by Mead and Ramsay in their study, suggests that, since $\left(I_{1}-I_{0}\right)$ and $\left(R_{1}-R_{0}\right)$ must be nonzero, "the performance of industries in the 1973-1975 recession, both nationally and within [Nebraska], does not prove to be a good indicator of their performance in the [1981-1982] recession" (Mead and Ramsay, 1982 , p. 41). Such a lack of stability means that using past behavior to design policies aimed at reducing statewide cyclical behavior in the future is likely to be difficult.

\section{Summary}

A comparison of nonagricultural employment trends at the national level during the 1973-1975 and 1981-1982 recessions underscores, albeit at a rather aggregative level, the similarity between the two recessions. Looking at the total employment performance of the Nebraska economy during these two down- 
turns, one is again struck by the similarity of the two episodes. While, as noted by Bretzfelder (1976), disparities in regional performance are especially notable on the downward leg of the business cycle, the performance of the Nebraska economy seems to be a rather good reflection of the national performance, although with a diminished amplitude.

While a traditional shift/share analysis comparing the Nebraska economy with that of the nation during the two recessionary periods suggests some shifts in the response of the state economy to national trends, the overall impression is one of similarity in the state's response to the two recessions. It is only through the use of the Mead/Ramsay model, with its greater disaggregation of the factors acting upon the regional economy, that we can strip the mask of similarity aside and see the countervailing forces "going on" in the state economy and accurately gauge the effects impinging on the Nebraska economy.

Application of this methodology shows that changes in the employment base $\left(\mathrm{E}_{1}-\mathrm{E}_{0}\right)$ of the Nebraska economy between 1973 and 1981 , as well as changes in the regional competitiveness of the local economy during the six year period between the onset of the two recessions, were significantly affected by the relative performance of the economy. Since both these dimensions can potentially be influenced by state development agencies, it appears that significant latitude exists for policy makers to effect the "immunity" of the state's economy to the national business cycle. ${ }^{5}$

Unfortunately, the lack of correlation between the 1973-1975 and 1981-1982 industrial mix and regional (competitive) effects, at the sectoral level, indicates that while this potential for countercyclical policy exists, more information than that provided by the methodology employed in this study must be garnered. Specifically, we need to better track and predict national industrial cyclical performance and regional linkages. Enter the business cycle theorist, the location theorist and the econometrician!

\section{INDUSTRIAL SECTORING PLAN}

\section{APPENDIX A}

TOTAL EMPLOYMENT
MANUFACTURING
Construction Materials
Furn \& Fixt
Metals
Machinery
Other Durables
Meat Products
Dairy Products
Grain Products
Other Food Products
Textile \& Apparel
Printing \& Publishing
Chemicals
Other Nondurables

TOTAL EMPLOYMENT

Construction Materials

Other Durables

Meat Products

Dairy Products

Other Food Products

Printing \& Publishing

Other Nondurables

\author{
MINING \\ CONSTRUCTION \\ Rail Transport \\ Other Transport \\ Commun \& Utilities \\ WHOLESALE \\ RETAIL \\ FIRE \\ Hotels \\ Personal Services \\ Business Services \\ Other Services \\ Federal Government \\ State Government \\ Local Government
}

INDUSTRIAL AND REGIONAL RESPONSE VECTORS BY INDUSTRY

APPENDIX B

\author{
MANUFACTURING \\ Construction Materials \\ Furn \& Fixt \\ Metals \\ Machinery \\ Other Durables \\ Meat Products \\ Dairy Products \\ Grain Products \\ Other Food Products
}

$$
\begin{array}{r}
E_{0} \times\left(I_{1}-I_{0}\right) \\
106.5158716 \\
261.6579665 \\
-669.475942 \\
-997.125247 \\
485.5194835 \\
364.2223850 \\
44.78397799 \\
128.8141149 \\
809.7776701
\end{array}
$$

$\mathrm{E}_{0} \times\left(\mathrm{R}_{1}-\mathrm{R}_{0}\right)$
556.7971593
228.8572010
-1050.88497
-1366.16612
116.0058021
-2514.77365
-322.520848
-563.784518
1715.213849 


\section{INDUSTRIAL AND REGIONAL RESPONSE VECTORS BY INDUSTRY}

$\begin{array}{lr} & \text { APPENDIX B } \\ \text { Textile \& Apparel } & 129.8665049 \\ \text { Printing \& Publ } & 21.69297489 \\ \text { Chemicals } & 148.0894953 \\ \text { Other Nondurables } & 463.6248298 \\ \text { MINING } & -280.727242 \\ \text { CONSTRUCTION } & 1201.103853 \\ \text { Rail Transport } & -1709.83248 \\ \text { Other Transport } & 694.3547389 \\ \text { Commun \& Util. } & 39.80003512 \\ \text { WHOLESALE } & -672.248567 \\ \text { RETAIL } & 2845.228443 \\ \text { FIRE } & -692.752203 \\ \text { Hotels } & -1520.80755 \\ \text { Personal Services } & 832.4213024 \\ \text { Business Services } & -335.656805 \\ \text { Other Services } & -1389.06206 \\ \text { Federal Government } & -1190.30804 \\ \text { State Government } & 667.1445624 \\ \text { Local Government } & -3002.9 \\ \text { TOTAL } & -3216.27794\end{array}$

$-387.259991$

$-212.422371$

62.85473774

$-581.487436$

499.6388984

3513.104234

612.7363638

$-388.775183$

$-1069.08454$

$-1958.81440$

$-362.691931$

$-698.825693$

1390.934216

$-577.876050$

1377.890366

$-764.852352$

1023.079612

$-1180.87952$

5914.533

3010.545839

\section{FOOTNOTES}

${ }^{1}$ It should be noted that the Nebraska economy usually tends to lag behind the national economy at the cyclical trough. In the 1981-1982 recession, for instance, the national trough was in November 1982; the Nebraska economy reached its nadir two months later. The purpose of this study, however, is to investigate the state's economic response to the national downturn; hence we adopt the NBER national benchmarks.

${ }^{2}$ Since we wish to avoid the confusion in terminology so often associated with traditional shift/share, we adopt the highly descriptive appellations used by Mead and Ramsay (1982).

${ }^{3}$ Equation (4) could be reformulated as a Paasche measure by using the 1981-1982 recession as the base recession. The results of the two formuations could then be averaged. Preliminary estimation of such an equation did not change the substantive conclusions advanced below.

'In both the 1973-1975 and 1981-1982 recessions, Food Products, especially Other Food Products (where the bulk of Nebraska's job loss was concentrated), exhibited a decline exceeding that of total nonagricultural employment at the national level.

${ }^{5}$ For a discussion of regional countercyclical issues and policy, see also references at the end of this paper.

\section{REFERENCES}

Barkley, David L. "Regional Manufacturing Employment
Cycles Revisited." The Annals of Regional Science. 15 (1981), 66-82.

Barth, James, John Kraft, and Philip Wiest. "A Portfolio Theoretic approach to Industrial Diversification and Regional Employment." Journal of Regional Science. 15 (1975), 9-15.

Bretzfelder, Richard B. "Contrasting Developments in States During Recessions and Early Recovery." Survey of Current Business. 56 (1976), 30-45.

Brown, Deborah J. and Jim Pheasant. "A Sharpe Portfolio Approach to Regional Economic Analysis." Jour nal of Regional Science. 24 (1985), 51-63.

Connaughton, John E. and Ronald A. Madsen. "Explaining Differentials in State Unemployment Rates During Recessions." Regional Science Perspectives. 14 (1984), 18-24.

Domazlicky, Bruce. "Regional Business Cycles: A Survey." Regional Science Perspectives. 10 (1980), 15-34.

Howland, Marie. "Age of Capital and Regional Business Cycles." Growth and Change. 12 (1984), 29-37.

Maki, Wilbur R., Carlo del Ninno, and Peter L. Stenberg. "Forecasting State Economic Growth in Recession and Recovery." Regional Science Perspectives. 13 (1983), 39-50.

Mead, Arthur C. and Glenworth A. Ramsay. "Analyzing Differential Responses of a Region to Business Cycles." Growth and Change. 13 (1982), 38-42.

Ramsay, G. A. and Mead, A.C. "The Classification of Industry by Employment Growth and Stability." Northeast Regional Science Review. 11 (1981), 43-63. 